ISSN: 2302-8556

E-Jurnal Akuntansi Universitas Udayana

Vol.25.1.Oktober (2018): 553-580

DOI: https://doi.org/10.24843/EJA.2018.v25.i01.p21

\title{
Pengaruh Employee Stock Option Plan (ESOP) pada Earnings Management dan Leverage Sebagai Variabel Pemoderasi
}

\section{Gusti Ngurah Bayu Kuta Waringin ${ }^{1}$ Luh Gede Krisna Dewi ${ }^{2}$}

\author{
${ }^{1}$ Fakultas Ekonomi dan Bisnis Universitas Udayana (Unud), Bali, Indonesia \\ email:bayukuta3@gmail.com/Telp :087862598930 \\ ${ }^{2}$ Fakultas Ekonomi dan Bisnis Universitas Udayana (Unud), Bali, Indonesia
}

\begin{abstract}
ABSTRAK
Tujuan penelitian ini adalah untuk mendapatkan bukti empiris kemampuan leverage memoderasi pengaruh ESOP pada manajemen laba. Populasi pada penelitian ini adalah perusahaan-perusahaan yang mendaftarkan sahamnya di Bursa Efek Indonesia tahun 2012-2016. Sampel pada penelitian ini diambil dengan menggunakan teknik purposive sampling berdasarkan teknik penentuan sampel dengan pertimbangan bahwa perusahaan sudah mencatatkan sahamnya dan mengumumkan ESOP di Bursa Efek Indonesia dalam periode 1 Januari 2012 sampai dengan 31 Desember 2016 serta memiliki data yang lengkap terkait dengan variabel yang digunakan dalam penelitian yaitu employee stock option plan, leverage, dan manajemen laba. Teknik analisis yang digunakan pada penelitian ini yaitu dengan menggunakan teknik Moderated Regression Analysis (MRA). Berdasarkan hasil penelitian menunjukkan bahwa leverage memperlemah pengaruh Employee Stock Option Plan (ESOP) pada manajemen laba perusahaan. Hal ini menunjukkan bahwa dengan adanya variabel leverage, maka pengaruh negatif ESOP terhadap manajemen laba akan semakin berkurang.
\end{abstract}

Kata kunci: Employee stock option plan, leverage, manajemen laba

ABSTRACT

The purpose of this study was to obtain empirical evidence of leverage ability to moderate the effect of ESOP on earnings management. The population in this study were companies that registered their shares on the Indonesia Stock Exchange in 2012-2016. The sample in this study was taken using purposive sampling technique based on the technique of determining the sample with the consideration that the company has listed its shares and announced the ESOP on the Indonesia Stock Exchange in the period 1 January 2012 to 31 December 2016.. The analysis technique used in this study is by using the Moderated Regression Analysis (MRA) technique. Based on the results of the study shows that leverage weakens the influence of the Employee Stock Option Plan (ESOP) on corporate earnings management. This shows that with the leverage variable, the negative influence of ESOP on earnings management will decrease.

Keywords: Employee stock option plan, leverage, earnings management

\section{PENDAHULUAN}

Laporan keuangan merupakan sarana pengkomunikasian informasi keuangan kepada pihak-pihak di luar korporasi. Laporan keuangan tersebut diharapkan dapat memberikan informasi kepada para investor dan kreditor dalam mengambil keputusan yang berkaitan dengan investasi dana mereka. Informasi laba sangat 
I G.N Bayu Kuta Waringin dan Luh Gede Krisna Dewi. Pengaruh...

penting perannya sebagai ukuran kerja perusahaan, sebagai dasar pembuatan berbagai keputusan penting oleh pengguna informasi. Earnings atau laba merupakan komponen keuangan yang menjadi pusat perhatian sekaligus dasar pengambilan keputusan bagi pihak-pihak yang berkepentingan, misalnya digunakan untuk menilai kinerja perusahaan ataupun kinerja manajer sebagai dasar untuk memberikan bonus kepada manajer dan juga digunakan sebagai penghitungan penghasilan kena pajak (Maiyusti, 2014).

Manajemen laba merupakan proses untuk mengambil langkah tertentu yang disengaja dalam batas batas prinsip akuntansi berterima umum untuk menghasilkan tingkat yang diinginkan dari laba yang dilaporkan.Alasan manajer melakukan manajemen laba didasarkan pada harga pasar saham suatu perusahaan yang secara signifikan dipengaruhi oleh laba, risiko, dan spekulasi. Oleh sebab itu, perusahaan yang labanya selalu mangalami kenaikan dari periode ke periode secara konsisten akan mengakibatkan risiko perusahaan mengalami penurunan lebih besar dibandingkan persentase kenaikan laba. Hal ini yang mengakibatkan banyak perusahaan yang melakukan pengelolaan dan pengaturan laba sebagai salah satu upaya untuk mengurangi risiko (Adriyani, 2011). Manajemen laba dinyatakan sebagai aktivitas yang lumrah dilakukan manajer dalam menyusun laporan keuangan karena upaya rekayasa manajerial ini dilakukan dalam ruang lingkup prinsip akuntansi. Pada prinsipnya manajemen laba dapat terjadi karena manajer diberikan beberapa keleluasaan untuk menerapkan standar akuntansi keuangan yang memungkinkan manajer untuk memilih metode yang akan digunakan dalam mengungkapkan informasi keuangan yang dimiliki perusahaan. 
Selain itu perilaku manipulasi ini juga terjadi karena adanya asimetri informasi yang tinggi antara manajemen dan pihak yang tidak mempunyai sumber, dorongan, akses yang memadai terhadap informasi untuk memonitor tindakan manajer (Adriyani, 2011)

Agency theory memaparkan bahwa adanya pemisahan antara kepemilikan dan pengelolaan perusahaan yang dapat menimbulkan konflik. Perbedaan tersebut terjadi karena masing-masing memiliki keanekaragaman karakter, tingkat intelektual dan kepentingan berbeda sehingga sangat rentan terjadi konflik keagenan di lingkungan internal perusahaan, salah satunya asimetri informasi. Fenomena asimetri informasi terjadi dimana kepemilikan informasi yang tidak seimbang serta cenderung didominasi oleh agen selaku pengelola untuk melakukan hal-hal tertentu yang mengganggu stabilitas perusahaan, misalnya pembuatan keputusan yang berkaitan dengan aktivitas pencairan dana dan pembuatan keputusan yang berkaitan dengan investasi. Dalam pengambilan keputusan perusahaan, seringkali terdapat perbedaan pendapat antara pemilik saham sebagai principal dengan manajer perusahaan sebagai agent. Untuk mengurangi perbedaan pendapat ini, pemilik saham dapat memberikan kompensasi kepada manajer. Menurut Nawawi (2003: 315), Kompensasi bagi organisasi/perusahaan berarti penghargaan/ganjaran pada para pekerja yang telah memberikan kontribusinya dalam mewujudkan tujuannya, melalui kegiatan yang disebut bekerja. Kompensasi ini, salah satunya dapat diberikan kepada karyawan dalam bentuk Employee Stock Option Plan (ESOP). 
I G.N Bayu Kuta Waringin dan Luh Gede Krisna Dewi. Pengaruh...

Employee Stock Option Plan (ESOP) merupakan program kompensasi yang memberikan kesempatan pada karyawan untuk dapat memiliki saham perusahaan. Munculnya ESOP didasari sebuah gagasan untuk mensejajarkan kepentingan karyawan (agent) dan para pemegang saham (principal) dengan tujuan untuk mengurangi konflik kepentingan antara agent dan principal (Bapepam, 2002). Dengan adanya ESOP, karyawan akan termotivasi untuk meningkatkan kinerjanya karena karyawan tersebut merasa memiliki perusahaan. Jika kinerja karyawan meningkat maka nilai perusahaan pun akan meingkat. Penelitian Anwar dan Baridwan (2006) membuktikan bahwa pengadopsian ESOP dapat meningkatkan produktivitas sebesar 4-5\%. Anwar dan Baridwan (2006) juga mencatat bahwa pendapatan perusahaan meningkat sebesar 3-6\%, yaitu ketika produktivitas sebelum dan sesudah pengadopsian ESOP diobservasi.

Penerapan ESOP diharapkan menjadi salah satu cara untuk dapat menarik perhatian para karyawan, dimana semua karyawan mendapatkan kesempatan dan berhak untuk memiliki saham pada perusahaan dimana mereka bekerja. Karena karyawan diberikan kesempatan untuk memiliki saham dalam perusahaan, maka setiap karyawan akan merasa ikut memiliki (sense of belonging) pada perusahaan mereka. Sehingga hasil yang diharapkan adalah karyawan akan termotivasi untuk memajukan perusahaan yang secara tidak langsung dapat meningkatkan nilai perusahaan itu sendiri (Hartono, 2014). Penelitian yang dilakukan oleh Ida (2009)menyatakan bahwa ESOP mempengaruhi manajemen laba. Hasilnya bahwa laba akan diturunkan menjelang pengumuman ESOP, laba akan ditingkatkan setelah pengumuman ESOP, dan semakin besar penurunan laba semakin besar 
pula peningkatan laba yang dilakukan setelah pengumuman ESOP. Dari pengujian yang dilakukan oleh Maiyusti (2014) menemukan bukti yang berbeda bahwa variable ESOP tidak berpengaruh terhadap manajemen laba. Meskipun ESOP memberikan hak suara tertentu kepada karyawan sebagai pemegang saham, namun pemegang saham pendiri jarang melepaskan pengendalian atas perusahaannya. Walaupun karyawan juga memiliki saham pada perusahaan, mereka tidak dapat mengontrol langsung kegiatan manajemen, sehingga program kepemilikan saham oleh karyawan ini tidak berpengaruh terhadap praktek manajemen laba.

Penelitian yang sudah dilakukan oleh beberapa peneliti menunjukan hasil yang tidak konsisten. Hal ini kemungkinan diakibatkan adanya faktor lain yang turut mempengaruhi hubungan ESOP dengan manajemen laba seperti leverage. Leverage merupakan pengukuran besarnya aktiva yang dibiayai dengan hutang. Hutang adalah salah satu alat yang dipergunakan perusahaan untuk meningkatkan modal mereka dalam rangka meningkatkan keuntungan (Singapurwoko, 2011). Pada umumnya bila hutang menjadi lebih besar dari modal sendiri, perusahaan dikatakan dalam kondisi yang tidak sehat karena seluruh modalnya tidak akan cukup untuk menanggung hutang (Andani dkk, 2010). Oleh karena pentingnya leverage dalam keberlangsungan sebuah perusahaan, maka dalam penelitian ini peneliti menggunakan leverage sebagai variabel pemoderasi pengaruh ESOP pada manajemen laba.

Berdasarkan latar belakang yang telah dipaparkan, maka yang menjadi pokok permasalahan dalam penelitian ini yaitu Apakah leverage memoderasi 
I G.N Bayu Kuta Waringin dan Luh Gede Krisna Dewi. Pengaruh...

pengaruh ESOP pada manajemen laba? Kemudian berdasarkan rumusan masalah tersebut, maka tujuan yang ingin dicapai dalam penelitian ini adalah untuk mendapatkan bukti empiris kemampuan leverage memoderasi pengaruh ESOP pada manajemen laba.

Teori agensi adalah teori yang menjelaskan tentang hubungan antara prinsipal dan agen. Teori agensi menyatakan bahwa hubungan keagenan timbul ketika salah satu pihak (prinsipal) memberi kuasa kepada pihak lain (agen) untuk melakukan beberapa jasa untuk kepentingannya untuk melibatkan pendelegasian beberapa otoritas pembuat keputusan kepada agen. Agen pun berkewajiban melakukan hal-hal yang memberikan manfaat dan meningkatkan kesejahteraan prinsipal (Jasen and Meckling, 1976). Hubungan ini diatur dalam kontrak yang disebut kontrak keagenan. Menurut Jesen and Meckling (1976) kontrak keagenan adalah kontrak diantara prinsipal dengan agen, dimana pelaksanaan tugas dan wewenang berada di tangan manajemen sesuai perintah pemilik perusahaan.

Teori agensi menjelaskan tentang konflik agensi yang dapat terjadi dalam hubungan keagenan. Adanya pemisah kepemilikan oleh prinsipal dan pengendalian oleh agen dalam sebuah organisasi cenderung menimbulkan konflik keagenan antara prinsipal dan agen. Prinsipal adalah pemegang saham atau investor, sedangkan agen adalah orang yang diberi kuasa oleh prinsipal yaitu manajemen yang mengelola perusahaan yang terdiri dari dewan komisaris dan dewan direksi. Teori keagenan juga berperan dalam menyediakan informasi sehingga akuntansi memberi umpan balik (feedbeck) selain nilai prediktifnya (Febriana dan Suaryana, 2011). 
Jika kedua belah pihak antaraprinsipal dan agen tersebut mempunyai tujuan yang sama untuk memaksimumkan nilai perusahaan, maka diyakini agen akan bertindak dengan cara yang sesuai dengan kepentingan prinsipal. Namun, seringkali terdapat perbedaan pendapat cara mencapai tujuan tersebut yang melibatkan kepentingan masing-masing pihak. Eisenhardt (1989)menyatakan bahwa teori agensi menggunakan tiga asumsi mengenai sifat manusia yakni, yaitu (1) asumsi sifat manusia (mementingkan diri pribadi, keterbatasan rasional, dan menghindari risiko), (2) asumsi keorganisasian (adanya konflik tujuan antara anggota), (3) asumsi informasi (informasi merupakan komoditi yang dapat dibeli).

Manajemen laba merupakan manipulasi aktif hasil akuntansi dengan tujuan membuat sebuah perubahan kesan atau opini dari performa sebuah bisnis (Mulford dan Comiskey, 2002). Schipper (1989) mendefinisikan manajemen laba sebagai suatu intervensi dengan tujuan tertentu dalam proses pelaporan keuangan eksternal untuk memperoleh beberapa keuntungan. Definisi lain dari Healy dan Wahlen (1999) yang menyatakan bahwa manajemen laba terjadi ketika manajer menggunakan pertimbangan dalam pelaporan keuangan dan membentuk transaksi untuk mengubah laporan keuangan. Hal ini dapat terjadi karena prinsipal memberi keleluasaan yang besar kepada manajer untuk terlibat dalam praktik akuntansi (Chiraz dan Anis, 2013).

Scott (2003: 351) menyatakan bahwa terdapat dua cara pandang dalam memahami manajemen laba yang dilakukan manajer perusahaan. Pertama, opportunistic behaviour di mana manajemen laba dilakukan untuk memaksimalkan utilitas manajemen. Kedua, efficient contracting yang bertujuan 
I G.N Bayu Kuta Waringin dan Luh Gede Krisna Dewi. Pengaruh...

untuk memberikan keuntungan kepada semua pihak yang terkait dalam kontrak. Christie and Zimmerman (1994) menyatakan bahwa efficiency contracting lebih mendominasi daripada opportunistic behaviour dalam menjelaskan perspektif manajemen laba. Hal tersebut dikarenakan prinsipal ternyata mampu mengantisipasi perilaku opportunistik manajer dan kemampuan prinsipal ini mendorong perspektif tersebut berubah menjadi efficiency contracting.

Manajemen laba dapat dilakukan dengan manajemen laba akrual dan manajemen laba riil. Manajemen laba riil (real activities manipulation) dapat terjadi sepanjang periode akuntansi sedangkan manajemen laba akrual (accrual manipulation) yaitu dengan discretionary accrual yang tidak memiliki pengaruh terhadap arus kas secara langsung dilakukan pada akhir periode ketika manajer mengetahui laba sebelum direkayasa sehingga diketahui berapa besar rekayasa yang diperlukan agar target laba tercapai (Sandyaswari, 2016).

Manajer bisa memanjemen laba dengan mengubah proses akrual karena berbagai estimasi dan pertimbangan manajer termasuk dalam persiapan pembuatan laporan akhir (Enomoto et al., 2015). Berdasarkan definisi manajemen laba maka dapat diyakini bahwa discretionary accrual mengukur tingkat laba yang dimanipulasi oleh manajer (Thi, 2015).

Program opsi saham, suatu perusahaan memberikan kepada karyawan secara perorangan hak kontraktual, atau opsi untuk membeli dengan jumlah tertentu atas saham perusahaan sepanjang periode waktu tertentu, membayar dengan harga yang ditetapkan pada saat tanggal pemberian. Periode waktu tersebut biasanya antara 5 (lima) sampai 10 (sepuluh) tahun dimulai pada tanggal 
pemberian dan harga saham biasanya sama dengan harga pasar wajar saham pada saat pemberian. Konsep dibalik opsi ini adalah jika saham perusahaan meningkat dalam tahun-tahun setelah pemberian, karyawan mendapatkan keuntungan dengan membeli saham pada harga lebih rendah yaitu harga yang berlaku pada waktu pemberian dan kemudian menjualnya dengan harga yang lebih tinggi, setelah harga meningkat. Nilai suatu opsi saham bagi karyawan sifatnya terkait pada kinerja perusahaan di masa yang akan datang.

Perusahaan dapat mengaitkan pemberian opsi kepada kinerja kelompok atau individual dalam berbagai cara. Sebagaimana dengan bonus kas, perusahaan bebas untuk memutuskan kepada siapa mereka akan memberikan opsi dan berapa banyaknya opsi yang akan mereka berikan kepada masing-masing individu. Pada masa lalu, perusahaan biasanya membatasi pemberian opsi saham hanya kepada manajemen dan pada beberapa anak perusahaan, dan program opsi saham masih menggunakan cara tersebut. Namun demikian, kini terdapat kecenderungan (peningkatan) bahwa perusahaan-perusahaan memberikan opsi saham lebih jauh ke dalam organisasinya, seringkali melibatkan seluruh karyawan. Opsi dapat menjadi suatu motivator yang lebih efektif dibandingkan suatu bonus kas, karena tidak seperti kas, opsi terus menerus berlaku sebagai suatu insentif yang baik bagi karyawan setelah mereka diberikan opsi, karena nilai sebenarnya akan ditentukan dengan kinerja perusahaan di masa mendatang (Arnita, 2015).

Berdasarkan kajian dari Bapepam (2002), bahwa perusahaan publik pada umumnya lebih memilih untuk menerapkan pendekatan dalam bentuk opsi saham karyawan (Employee Stock Option Plan atau ESOP), karena apabila dibandingkan 
I G.N Bayu Kuta Waringin dan Luh Gede Krisna Dewi. Pengaruh...

dengan pendekatan kompensasi lainnya, ESOP lebih memiliki potensi untuk mendorong karyawan memberikan kinerja terbaiknya dalam kurun waktu yang panjang.

Leverage merupakan alat untuk mengukur seberapa besar perusahaan tergantung pada kreditur dalam membiayai aset perusahaan. Perusahaan yang mempunyai tingkat leverage tinggi berarti sangat bergantung pada pinjaman luar untuk membiayai asetnya, sedangkan perusahaan yang mempunyai tingkat leverage lebih rendah lebih banyak membiayai asetnya dengan modal sendiri. Jadi dapat dikatakan bahwa tingkat leverage perusahaan menggambarkan risiko keuangan perusahaan (Sari, 2012).

Hasil penelitian mengenai pengaruh employee stock option plan (ESOP) pada Earnings Management yang tidak konsisten menunjukkan adanya faktor lain yang turut menginteraksi. Hasil tersebut mendorong peneliti untuk memasukkan leverage sebagai variabel pemoderasi. Teori agensi menyatakan bahwa dalam perusahaan, hubungan antara principal dan agent diwujudkan dalam hubungan antara pemegang saham dan manajer (Christiawan dan Tarigan, 2007). Pemegang saham berperan sebagai principal sementara manajer berperan sebagai agent. Hubungan ini menimbulkan suatu kontrak antara pemegang saham dan manajer. Hubungan kontrak ini memungkinkan terjadinya konflik kepentingan (conflict of interest) antara pemegang saham dan manajer (Ross, Westerfield, Jaffe, 2010). Opsi saham dapat diberikan melalui Employee Stock Option Plans (ESOP). Menurut Riaz and Waqar (2017) Employee Stock Option Plans (ESOP) dapat meningkatkan produktivitas ataupun profitabilitas suatu perusahaan. Employee 
Stock Option Plans (ESOP) mampu mempengaruhi keseluruhan organisasi secara positif. Selain itu ESOP mempunyai manfaat yang penting terhadap peningkatan kinerja perusahaan, pengaruh terhadap kesejahteraan karyawan dan penyelarasan kepentingan karyawan dan eksekutif perusahaan dengan pemegang saham. Hal ini akan menurunkan tindakan pegawai dan pejabat eksekutif untuk melakukan manajemen laba karena akan menanggung baik dan buruknya akibat dari tindakan yang diambil. Besarnya tingkat leverage dapat mempengaruhi tindakan manajemen laba. Leverage yang tinggi yang disebabkan kesalahan manajemen dalam mengelola keuangan perusahaan atau penerapan strategi yang kurang tepat dari pihak manajemen. Oleh karena kurangnya pengawasan yang menyebabkan leverage yang tinggi, juga akan meningkatkan tindakan manajemen laba untuk mempertahankan kinerjanya di mata pemegang saham dan publik. Berdasarkan pernyataan dan hasil penelitian tersebut, maka dapat ditarik hipotesis sebagai berikut.

$\mathrm{H}_{1}$ : Semakin tinggi Employee Stock Option Plan (ESOP), maka semakin berkurang Earning Management terutama pada perusahaan yang memiliki leverage tinggi

Berdasarkan landasan teori dan kajian empiris pada penelitian terdahulu, maka secara sistematis, kerangka konseptual dalam penelitian dapat digambarkan sebagai berikut:

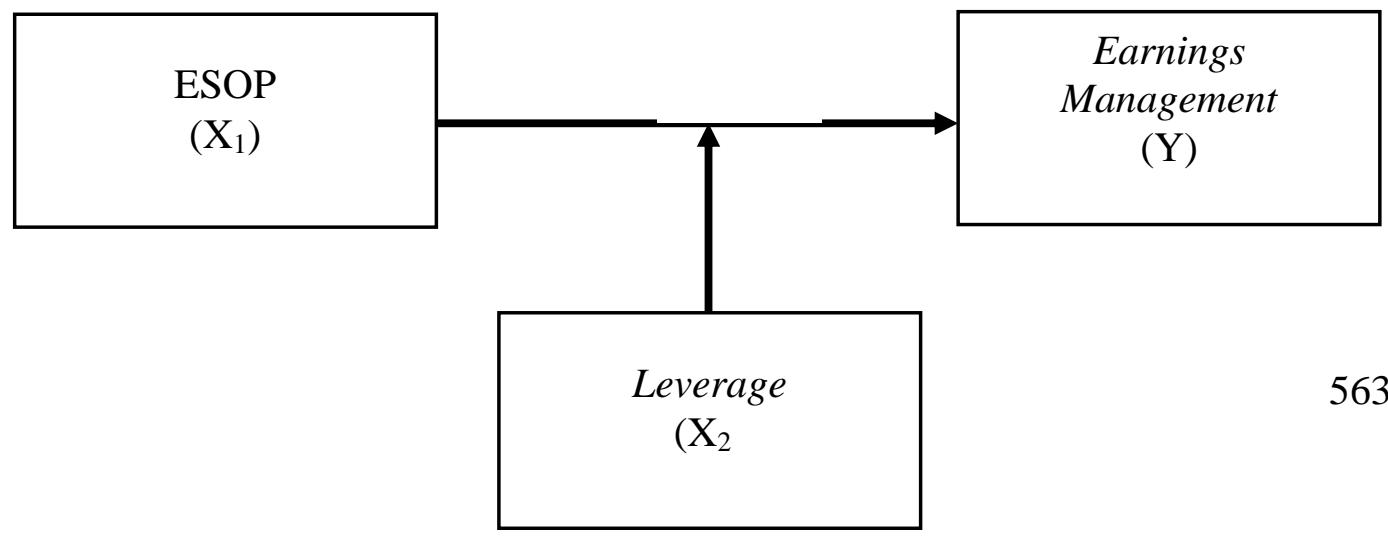




\section{Gambar 1. Kerangka Konseptual}

\section{METODE PENELITIAN}

Penelitian ini merupakan penelitian asosiatif kuantitatif yaitu penelitian yang meneliti pengaruh suatu variabel terhadap variabel lainnya atau mengetahui hubungan antar variabel Employee Stock Option Plan (ESOP) Pada Earnings Management Dengan Leverage Sebagai Variabel Pemoderasi

Penelitian ini dilakukan pada perusahaan yang terdaftar di Bursa Efek Indonesia (BEI) pada tahun 2012-2016.Obyek dalam penelitian ini adalah employee stock option plan (ESOP), nilai perusahaan, dan leverage pada perusahaan yang terdaftar di Bursa Efek Indonesia (BEI) pada tahun 2012-2016.

Variabel terikat (Y) dalam penelitian ini adalah manajemen laba (Y) yang diukur dengan proksi Discretionary Accrual Modified Jones Model. Model ini lebih mampu mendeteksi tingkat manajemen laba dibandingkan dengan model estimasi lain karena memberikan hasil yang lebih akurat. Model ini mempunyai standar eror hasil regresi estimasi nilai total akrual yang paling kecil dibandingkan dengan model lainnya (Dechow, 1995). Rumus perhitungan manajemen laba dalam penelitian ini adalah sebagai berikut:

DTAC $=\left(\frac{\text { TACit }}{\text { TAit }-1}\right)-N D T A C i t$

Variabel bebas (X) dalam penelitian ini adalah employee stock option plan $(\mathrm{ESOP})(\mathrm{X})$.Variabel pengumuman ESOP akan diproksikan dengan proporsi opsi saham, yang didapat dengan membandingkan jumlah opsi saham pada saat 
pengumuman ESOP dengan keseluruhan jumlah saham yang dimiliki perusahaan. Besar atau kecilnya jumlah opsi saham dilakukan perusahaan akan tercermin dari nilai proporsi opsi saham di tahun pengumuman ESOP perusahaan yang bersangkutan. Rumus proporsi opsi saham yaitu (Arnita, 2015) :

Proporsi Opsi Saham $=\frac{\text { Jumla } h \text { saham yang dimiliki karyawan }}{\text { jumla } h \text { saham beredar }}$

Variabel moderasi dalam penelitian ini adalah leverage (M). Leverage menunjukkan seberapa besar aset perusahaan yang diperoleh ataudidanai dari utang. Variabel ini diukur dengan menggunakan debt to total asset ratio, yaitu mengukur jumlah persentase dari jumlah dana yangdiberikan oleh kreditur berupa utang terhadap jumlah aset perusahaan. Utangtersebut termasuk utang lancar, obligasi dan kewajiban jangka panjanglainnya (Raharjaputra, 2009:201). Rumus perhitungannya yaitu:

$\mathrm{DAR}=\frac{\text { Total utang }}{\text { Tota } l \text { aset }} \times 100 \%$

Populasi dalam penelitian ini adalah perusahaan yang terdaftar di Bursa Efek Indonesia tahun 2012-2016.Sampel pada penelitian ini diambil dengan menggunakan teknik purposive sampling yaitu teknik penentuan sampel dengan pertimbangan tertentu yaitu : Perusahaan mencatatkan sahamnya di Bursa Efek Indonesia dalam periode 1 Januari 2012 sampai dengan 31 Desember 2016, kemudian perusahaan mengumumkan ESOP dalam periode 1 Januari 2012 sampai dengan 31 Desember 2016 dan memiliki data yang lengkap terkait dengan variabel yang digunakan dalam penelitian yaitu employee stock option plan, leverage, dan manajemen laba. 
I G.N Bayu Kuta Waringin dan Luh Gede Krisna Dewi. Pengaruh...

Teknik analisis yang digunakan pada penelitian ini yaitu dengan menggunakan teknik Moderated Regression Analysis (MRA) dengan menggunakan program SPSS (Statistical Product and Service Solution). Teknik ini digunakan untuk melihat pengaruh employee stock option plan terhadap nilai perusahaan dengan leverage sebagai variabel pemoderasi. Tahapan analisis dalam penelitian ini yaitu: Uji Asumsi Klasik, Perumusan Model Moderated Regression Analysis (MRA), Analisis Koefisien Determinasi, Uji Kesesuaian Model, dan Uji t. Secara sistematis persamaan regresi yang diperoleh yakni:

$Y=a+\beta_{1} X_{1}+\beta_{2} X_{2}+\beta_{3} X_{1} X_{2}+e$

Keterangan:

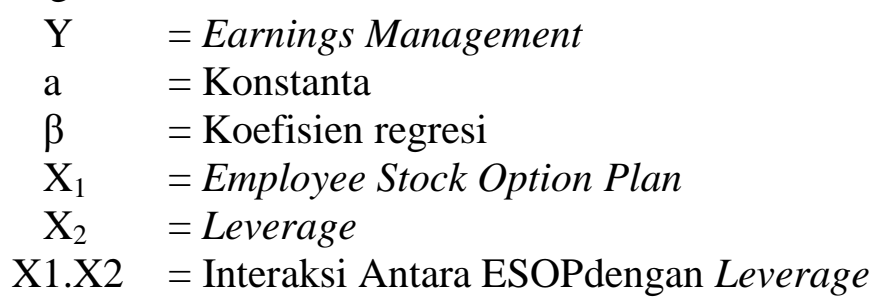

\section{HASIL DAN PEMBAHASAN}

Penelitian ini dilakukan pada perusahaan - perusahaan yang mendaftarkan sahamnya di Bursa Efek Indonesia dari tahun 2012 sampai tahun 2016. Pengamatan penelitian dilakukan pada perusahaan yang mengadopsi ESOP pada rentang waktu pengamatan yaitu tahun 2012-2016. Penelitian ini menggunakan pendekatan cross sectional yaitu hanya meneliti pada waktu tertentu saja.

Waktu pengamatan yang dipilih oleh peneliti yaitu pada tahun pengumuman ESOP. Sampel yang digunakan dalam penelitian ini dipilih secara purposive sampling, sehingga sampel yang digunakan dapat menjelaskan dari populasi dan 
sesuai dengan tujuan dari penelitian. Data sekunder yang diperoleh kemudian dipilih berdasarkan kriteria-kriteria yang telah ditentukan, maka diperoleh sebanyak 43 sampel data yang akan diamati. Proses seleksi berdasarkan kriteria yang telah ditetapkan, disajikan dalam Tabel 1.

Tabel 1.

Proses Pemilihan Sampel Penelitian

\begin{tabular}{ccc}
\hline No & Kriteria & $\begin{array}{c}\text { Jumlah } \\
\text { Perusahaan } \\
\text { Tersedia }\end{array}$ \\
\hline $1 \quad \begin{array}{c}\text { laan mencatatkan sahamnya di Bursa Efek Indonesia dalam periode } \\
\text { 1 Januari 2012 sampai dengan 31 Desember 2016. }\end{array}$ & 539 \\
$2 \quad \begin{array}{l}\text { laan tidak mengumumkan ESOP dalam periode 1 Januari 2012 } \\
\text { sampai dengan 31 Desember 2016 dan tidak memiliki data yang } \\
\text { lengkap terkait dengan variabel yang digunakan dalam penelitian } \\
\text { yaitu employee stock option plan, leverage, dan manajemen laba. } \\
\text { Total Sampel yang memenuhi kriteria }\end{array}$ & (496) \\
\hline Sumber: Data diolah, 2018
\end{tabular}

Data pada Tabel 1 menunjukan sampel yang diteliti sebanyak 43 perusahaan dengan pengamatan periode pengumuman ESOP. Setiap sampel perusahaan yang diteliti diharapkan dapat mewakili keadaan yang sesungguhnya.

Deskripsi variabel penelitian menyampaikan informasi mengenai karakteristik variabel-variabel penelitian yang terdari dari jumlah pengamatan, nilai minimum, nilai maksimum, nilai rata dan standar deviasi. Tabel 2 memperlikatkan hasil analisis statistik deskriptif.

Tabel 2.

Statistik Deskriptif

\begin{tabular}{lrrrrr}
\hline & N & Minimum & Maximum & Mean & Std. Deviation \\
\hline ESOP & 43 & .0037 & .9938 & .471840 & .3319117 \\
Leverage & 43 & .0595 & 2.1845 & .845160 & .5292190 \\
Earnings Management & 43 & .0625 & 2.4476 & .723263 & .6361584 \\
Valid N (listwise) & 43 & & & & \\
\hline
\end{tabular}

Sumber: Data diolah, 2018

Dari hasil uji statistik deskriptif pada Tabel 2 didapatkan informasi bahwa

Employee Stock Option Plan (ESOP)paling rendah (minimum) adalah sebesar 
I G.N Bayu Kuta Waringin dan Luh Gede Krisna Dewi. Pengaruh...

0,0037 dimiliki oleh PT. Waskita Karya Tbk. pada tahun 2013. Nilai Employee Stock Option Plan yang paling tinggi (maksimum) adalah sebesar 0,9938 yang dimiliki oleh PT. BFI Finance Indonesia Tbk. pada tahun 2012. Employee Stock Option Plan memiliki nilai rata-rata sebesar 0,471840 dengan nilai standar deviasi sebesar 0,3319. Ini berarti bahwa terjadi perbedaan nilai Employee Stock Option Plan yang diteliti terhadap nilai rata-ratanya sebesar 0,3319 , yang artinya bahwa nilai mean lebih besar dari pada standar deviasi, sehingga mengindikasikan bahwa hasil yang cukup baik.

Leverage paling rendah (minimum) adalah sebesar 0,0595 dimiliki oleh PT Tiga Pilar Sejahtera Food Tbk pada tahun 2014 dan leverage yang paling tinggi (maksimum) adalah sebesar 2,1845 yang dimiliki oleh PT. Bank Bukopin Tbk. pada tahun 2014. Leverage memiliki nilai rata-rata sebesar 0,84516 dengan nilai standar deviasi sebesar 0,529219. Ini berarti bahwa terjadi perbedaan nilai leverage yang diteliti terhadap nilai rata-ratanya sebesar 0,529219, yang artinya bahwa nilai mean lebih besar dari pada standar deviasi, sehingga mengindikasikan bahwa hasil yang cukup baik.

Earnings managementpaling rendah (minimum) adalah sebesar 0,0625 dan earnings managementyang paling tinggi (maksimum) adalah sebesar 2,4476 yang dimiliki oleh PT. Bank Tabungan Negara Tbk. pada tahun 2016. Earnings managementmemiliki nilai rata-rata sebesar 0,723263 dengan nilai standar deviasi sebesar 0,63615. Ini berarti bahwa terjadi perbedaan nilai Earnings management yang diteliti terhadap nilai rata-ratanya sebesar 0,63615, yang artinya bahwa nilai 
mean lebih besar dari pada standar deviasi, sehingga mengindikasikan bahwa hasil yang cukup baik.

Analisis regresi sangat memerlukan bagian asumsi agar model dapat digunakan sebagai alat prediksi baik. Oleh karena itu dalam penelitian ini dilakukan uji asumsi klasik yang meliputi uji normalitas, uji autokolerasi, dan uji heteroskedastisitas.

Uji normalitas bertujuan untuk menguji apakah dalam model regresi, variabel pengganggu atau residual memiliki distribusi normal atau tidak. Model regresi yang baik adalah memiliki distribusi normal atau mendekati normal (Ghozali, 2012:116). Untuk mendeteksi normalitas data digunakan KolmogorovSmirnov dengan kriteria jika Asymp. Sig (2-tailed) lebih besar dari level of significant yang dipakai yaitu 5 persen, maka dapat disimpulkan bahwa residual berdistribusi normal namun sebaliknya jika Asymp. Sig (2-tailed) lebih kecil dari level of significant 5 persen, maka data mempunyai distribusi tidak normal. Hasil uji normalitas untuk selurih sampel dapat dilihat pada Tabel 3 di bawah ini.

Tabel 3.

Hasil Uji Normalitas

\begin{tabular}{llr}
\hline & One-Sample Kolmogorov-Smirnov Test & $\begin{array}{c}\text { Unstandardized } \\
\text { Residual }\end{array}$ \\
\hline $\mathrm{N}$ & & 43 \\
Normal Parameters ${ }^{\mathrm{a}, \mathrm{b}}$ & Mean & .0000000 \\
& Std. Deviation & .51544461 \\
Most Extreme Differences & Absolute & .118 \\
& Positive & .118 \\
Kolmogorov-Smirnov Z & Negative & -.070 \\
Asymp. Sig. (2-tailed) & & .775 \\
\hline Sumber: Data diolah, 2018 & & .585 \\
\hline
\end{tabular}

Hasi uji normalitas dengan uji Kolmogorov-Smirnov pada analisis regresi moderasi menunjukkan nilai Asymp. Sig (2-tailed) 0,585 lebih besar dari level of 
I G.N Bayu Kuta Waringin dan Luh Gede Krisna Dewi. Pengaruh...

significant, yaitu 5 persen $(0,05)$, sehingga data yang diuji menyebar normal atau berdistribusi normal.

Uji autokorelasi dilakukan untuk melacak adanya korelasi data dari tahun $\mathrm{t}$ dengan tahun t-1 (sebelumnya). Pengujian autokorelasi dilakukan melalui DurbinWatson test, dimana model regresi dikatakan terbebas dari autokorelasi apabila sesuai dengan kriteria du<DW $<4$-du. Hasil uji autokorelasi dapat dilihat pada Tabel 4 berikut:

Tabel 4.

Hasil Uji Autokorelasi

\begin{tabular}{lllll}
\hline \multicolumn{1}{c}{ Persamaan } & dl & )u & )W & Simpulan \\
\hline$\beta_{1} \mathrm{X}_{1}+\beta_{2} \mathrm{X}_{2}+\beta_{3} \mathrm{X}_{1} \mathrm{X}_{2}+\mathrm{e}$ & & & & tutokorelasi \\
\hline Sumber: Data diolah, 2018 & & & &
\end{tabular}

Tabel 4 menunjukkan bahwa pada persamaan regresi linear berganda memiliki nilai Durbin-Watson sebesar 1,861. Untuk tingkat signifikansi 5\%, nilai $\mathrm{dl}=1,3663$ dan $\mathrm{du}=1,663$. Dengan demikian hasil uji autokorelasi dengan kriteria $\mathrm{du}<\mathrm{DW}<4$-du adalah $1,663<1,861<2,337$, maka dapat disimpulkan bahwa model regresi yang dibuat tidak mengandung gejala autokorelasi.

Uji heteroskedastisitas dilakukan untuk menguji model regresi apakah terjadi ketidaksamaan varian dari residual satu pengamatan ke pengamatan lain. Uji heteroskedastisitas pada penelitian ini menggunakan uji Glejser. Uji Glejser dilakukan dengan cara meregresi nilai absoluteresidual dari model yang diestimasi terhadap variabel bebas. Jika nilai signifikannya lebih dari 0,05 maka tidak terjadi gejala heteroskedastisitas. Hasil uji Glejser dapat di lihat pada tabel 5. 


\begin{tabular}{clcc}
\hline Persamaan & \multicolumn{1}{c}{ Variabel } & t & Sig \\
\hline$\beta_{1} \mathrm{X}_{1}+\beta_{2} \mathrm{X}_{2}+\beta_{3} \mathrm{X}_{1} \mathrm{X}_{2}+\mathrm{e}$ & ee Stock Option Plan $\left(\mathrm{X}_{1}\right)$ & 188 & 0,852 \\
& ,e $\left(\mathrm{X}_{2}\right)$ &, 100 & 0,921 \\
& ;i antara ESOP dengan Leverage \\
$\left(\mathrm{X}_{1} * \mathrm{X}_{2}\right)$ & 872 & 0,388 \\
& &
\end{tabular}

Sumber: Data diolah, 2018

Tabel 5 menunjukkan bahwa nilai signifikansi Employee Stock Option Plan $\left(\mathrm{X}_{1}\right)$ sebesar 0,852, Leverage $\left(\mathrm{X}_{2}\right)$ sebesar 0,921, dan Interaksi antara ESOP dengan Leverage $\left(\mathrm{X}_{1} \cdot \mathrm{X}_{2}\right)$ sebesar 0,388 . Hasil uji tersebut memiliki nilai yang lebih besar dari $\alpha=0.05$. Oleh karena itu, dapat disimpulkan bahwa tidak terjadi heteroskedastisitas.

Untuk mengetahui apakah variabel leverage mampu memoderasi pengaruh variabel Employee Stock Option Plan terhadap Earnings Management, maka digunakan model pengujian interaksi (Moderated Regression Analysis-MRA). Model ini bertujuan untuk mengetahui apakah variabel moderasi mampu mempengaruhi hubungan antara variabel bebas dan variabel terikat, dimana dalam persamaan regresinya mengandung unsur interaksi. Hasil analisis uji interaksi dengan menggunakan program SPSS dapat dilihat pada tabel 6.

Tabel 6.

\begin{tabular}{|c|c|c|c|c|c|}
\hline \multicolumn{6}{|c|}{ Hasil Uji Interaksi (Moderated Regression Analysis) } \\
\hline Model & $\begin{array}{r}\text { Unsta } \\
\text { Coe }\end{array}$ & $\begin{array}{l}\text { ndardized } \\
\text { fficients }\end{array}$ & $\begin{array}{l}\text { Standardized } \\
\text { Coefficients }\end{array}$ & & \\
\hline & B & Std. Error & Beta & $\mathbf{t}$ & Sig. \\
\hline 1 (Constant) & .875 & .253 & & 3.457 & .001 \\
\hline ESOP & -.879 & 257 & -.459 & -3.415 & .002 \\
\hline Leverage & .040 & 160 & 033 & 250 & .804 \\
\hline Interaksi Antara ESOP dengan Leverage & .405 & 180 & 296 & 2.250 & .030 \\
\hline
\end{tabular}


I G.N Bayu Kuta Waringin dan Luh Gede Krisna Dewi. Pengaruh...

Berdasarkan hasil analisis regresi linier berganda seperti yang disajikan pada Tabel 6, maka persamaan strukturalnya adalah sebagai berikut :

$$
Y=0,875-0,879 X_{1}+0,040 X_{2}+0,405 X_{1} X_{2}+\varepsilon
$$

Nilai koefisien regresi variabel Employee Stock Option Plan bernilai negatif dengan nilai signifikansi uji t kurang dari 0,05. Hal ini menunjukkan bahwa variabel Employee Stock Option Plan memiliki pengaruh negatif yang signifikan terhadap variabel terikat. Nilai koefisien regresi variabel leverage bernilai positif dengan nilai signifikansi uji t lebih dari 0,05. Hal ini menunjukkan bahwa variabel leverage tidak berpengaruh secara signifikan terhadap variabel terikat. Sedangkan Nilai koefisien regresi variabel Interaksi Antara ESOPdengan Leverage bernilai positif dengan nilai signifikansi uji t lebih dari 0,05. Hal ini menunjukkan bahwa variabel Interaksi Antara ESOPdengan Leverage berpengaruh secara positif signifikan terhadap variabel terikat.

Untuk mengetahui dan mengukur kemampuan model dalam menerangkan variasi variabel independen digunakan koefisien determinasi $\left(\mathrm{R}^{2}\right)$. Peneliti menggunakan nilai adjusted $\mathrm{R}^{2}$ pada saat mengevaluasi yang mana model regresi terbaik, karena tidak seperti $\mathrm{R}^{2}$, nilai adjusted $\mathrm{R}^{2}$ (koefisien determinasi yang telah disesuaikan) dapat naik atau turun apabila satu variabel independen ditambahkan ke dalam model.

Tabel 7.

Uji Koefisien Determinasi

\begin{tabular}{lrrrr}
\hline Model & R & R Square & Adjusted R Square & $\begin{array}{c}\text { Std. Error of the } \\
\text { Estimate }\end{array}$ \\
\hline 1 & $.586^{\text {a }}$ & .344 & .293 & .5349022 \\
\hline Sumber $:$ Data diolah, 2018 & & &
\end{tabular}


Hasil uji koefisien determinasi dalam Tabel 7 menunjukkan besarnya nilai adjusted $\mathrm{R}^{2}$ adalah sebesar 0,293. Ini berarti variasi Earnings Management dapat dipengaruhi secara signifikan oleh variabel Employee Stock Option Plan, leverage, dan variabel interaksi antara ESOPdengan Leverage sebesar 29,3 persen sedangkan sisanya sebesar 70,7 persen dijelaskan oleh faktor-faktor lain.

Uji kesesuaian model regresi bertujuan untuk mengetahui apakah semua variabel bebas yang diidentifikasi (Employee Stock Option Plan, leverage, dan variabel interaksi antara ESOPdengan Leverage) tepat digunakan memprediksi Earnings Management. Uji ini sering juga disebut dengan uji F.

Tabel 8.

Hasil Uji F

\begin{tabular}{llrrrrr}
\hline Model & & Sum of Squares & df & Mean Square & F & Sig. \\
\hline 1 & Regression & 5.839 & 3 & 1.946 & 6.802 & $.001^{\mathbf{a}}$ \\
& Residual & 11.159 & 39 & .286 & & \\
& Total & 16.997 & 42 & & & \\
\hline
\end{tabular}

Sumber: Data diolah, 2018

Hasil uji $\mathrm{F}$ (Ftest) menunjukkan bahwa nilai signifikansi $\mathrm{P}$ value 0,001 yang lebih kecil dari $\alpha=0,05$, ini berarti model yang digunakan pada penelitian ini adalah layak. Hasil ini memberikan makna bahwa seluruh variabel independen yaitu Employee Stock Option Plan, leverage, dan variabel interaksi antara ESOPdengan Leverage mampu memprediksi atau menjelaskan fenomena Earnings Management padaseluruh sampelperusahaan yang mendaftarkan sahamnya di Bursa Efek Indonesia tahun 2012-2016. Hal ini berarti model dapat digunakan untuk analisa lebih lanjut atau dengan kata lain model dapat digunakan untuk memproyeksikan karena hasil goodness of fitnya baik dengan nilai signifikansi P value 0,001. 
I G.N Bayu Kuta Waringin dan Luh Gede Krisna Dewi. Pengaruh...

Berdasarkan hasil uji analisis regresi moderasi, pada Tabel 6 menunjukkan pengaruh employee stock option plan (ESOP) pada Earnings Management $\left(\mathrm{b}_{1}\right)$ diperoleh nilai signifikansi sebesar 0,002 (significant) dengan nilai koefisien regresi sebesar -0.879. Nilai signifikansi variabel moderasi leverage pada Earnings Management $\left(\mathrm{b}_{2}\right)$ sebesar 0,804 (non significant) dan nilai signifikan variabel interaksi antara ESOPdengan Leveragepada Earnings Management $\left(\mathrm{b}_{3}\right)$ signifikan sebesar 0,030 , hal ini mengindikasikan variabel moderasi merupakan tipe moderasi murni (pure moderasi), karena koefisien $\mathrm{b}_{2}$ non significant dan koefisienb $_{3}$ significant. Pure moderasi merupakan variabel yang memoderasi hubungan antara variabel prediktor dan variabel tergantung di mana variabel moderasi murni berinteraksi dengan variabel prediktor tanpa menjadi variabel prediktor (Solimun, 2010:33).

Hasil analisis regresi moderasi pada Tabel 6 menunjukkan bahwa nilai koefisien regresi employee stock option plan $\left(\beta_{1}\right)$ negatif signifikan dan variabel interaksi antara ESOPdengan Leverage $\left(\beta_{3}\right)$ positif signifikan, maka variabel leverage $\left(\mathrm{X}_{2}\right)$ merupakan variabel moderasi yang memperlemah pengaruh Employee Stock Option Plan (ESOP) pada manajemen laba.

Hasil analisis regresi moderasi menunjukkan bahwa leverage secara statistik mampu memoderasi pengaruh Employee Stock Option Plan (ESOP) pada manajemen laba. Pada penelitian ini, leverage memperlemah pengaruh Employee Stock Option Plan (ESOP) pada manajemen laba $\left(\mathrm{H}_{1}\right.$ diterima). Hal ini menunjukkan bahwa dengan adanya variabel leverage, maka pengaruh negatif ESOP terhadap manajemen laba akan semakin berkurang.Teori agensi 
menyatakan bahwa dalam perusahaan, hubungan antara principal dan agent diwujudkan dalam hubungan antara pemegang saham dan manajer (Christiawan dan Tarigan, 2007). Pemegang saham berperan sebagai principal sementara manajer berperan sebagai agent. Hubungan ini menimbulkan suatu kontrak antara pemegang saham dan manajer. Hubungan kontrak ini memungkinkan terjadinya konflik kepentingan (conflict of interest) antara pemegang saham dan manajer (Ross, Westerfield, Jaffe, 2010). Opsi saham dapat diberikan melalui Employee Stock Option Plans (ESOP). Menurut Brenner et al, (2000) ESOP merupakan langkah efektif untuk mempersempit masalah keagenan dan menurunkan agency cost melalui penyejajaran kepentingan para eksekutif dengan para pemegang saham.

Memberikan suatu insentif berupa saham kepada karyawan, yang diharapkan insentif tersebut memberikan dampak positif berupa motivasi dan komitmen karyawan tersebut, yang pada akhirnya memberikan peningkatan kepada produktivitas dan profitabilitas perusahaan tersebut. Selain itu ESOP mempunyai manfaat yang besar terhadap peningkatan kinerja perusahaan, pengaruh terhadap kesejahteraan karyawan dan penyelarasan kepentingan karyawan dan eksekutif perusahaan dengan pemegang saham. Hal ini akan menurunkan tindakan pegawai dan pejabat eksekutif untuk melakukan manajemen laba karena akan menanggung baik dan buruknya akibat dari tindakan yang diambil. Besarnya tingkat leverage dapat mempengaruhi tindakan manajemen laba. Leverage yang tinggi yang disebabkan kesalahan manajemen dalam mengelola keuangan perusahaan atau penerapan strategi yang kurang tepat dari 
I G.N Bayu Kuta Waringin dan Luh Gede Krisna Dewi. Pengaruh...

pihak manajemen. Oleh karena kurangnya pengawasan yang menyebabkan leverage yang tinggi, juga akan meningkatkan tindakan manajemen laba untuk mempertahankan kinerjanya di mata pemegang saham dan publik.

Implikasi dari hasil penelitian ini mencakup dua hal, yaitu implikasi teoritis dan praktis. Implikasi teoritis dalam penelitian ini diharapkan dapat memberikan kontribusi mengenai pengaruh employee stock option plan (ESOP) pada manajemen laba dengan leverage sebagai variabel moderasi. Hasil uji hipotesis dalam penelitian ini ditemukan bahwa Leverage secara statistik mampu memoderasi pengaruh Employee Stock Option Plan (ESOP) pada manajemen laba, sehingga variabel tersebut dapat dipertahankan sebagai variabel pemoderasi.

Implikasi praktis pada penelitian ini yaitu memberikan implikasi bagi investor sebagai pertimbangan dan pengetahuan mengenai manajemen laba serta faktor-faktor yang memengaruhinya. Investor dalam melakukan investasi atau penanaman modal di suatu perusahaan dapat melihat Employee Stock Option Plan (ESOP) danleverage yang dimiliki oleh perusahaan, karena hal tersebut dapat mempengaruhi manajemen laba.

\section{SIMPULAN}

Simpulan yang dapat diberikan berdasarkan hasil penelitian yang dilakukan yaitu leverage secara statistik mampu memoderasi pengaruh Employee Stock Option Plan (ESOP) pada manajemen laba. Pada penelitian ini, leverage memperlemah pengaruh Employee Stock Option Plan (ESOP) pada manajemen laba. Hal ini menunjukkan bahwa semakin tinggi Employee Stock Option Plan (ESOP), maka 
semakin berkurang Earning Management terutama pada perusahaan yang memiliki leverage tinggi.

Adapun saran yang dapat diberikan berdasarkan hasil penelitian yang dilakukan yaitu perusahaan hendaknya lebih memperhatikan program Employee Stock Option Plan agar dapat diterapkan dengan lebih efektif, karena proporsi opsi saham yang beredar di perusahaan mampu untuk menarik minat karyawan untuk turut serta di dalam memiliki perusahaan dan bersedia menanggung baik dan buruknya akibat dari tindakan yang diambil sehingga akan menurunkan tindakan pegawai dan pejabat eksekutif untuk melakukan manajemen laba.

Saran bagi penelitian selanjutnya yakni sebaiknya dapat mempertimbangkan untuk menggunakan objek penelitian selain Perusahaan yang terdaftar di Bursa Efek Indonesia (BEI) selama periode 2012 sampai dengan 2016. Penelitian selanjutnya juga disarankan untuk menambahkan variabel bebas ataupun variabel moderasi lainnya untuk menunjang kompleksitisitas penelitian, serta dapat menambah jumlah periode pengamatan agar memperoleh hasil yang lebih bagus untuk melakukan riset.

\section{REFERENSI}

Adriyani. 2011. Pengaruh Asimetri Informasi, Struktur Kepemilikan dan Rasio Profitabilitas terhadap Manajemen Laba pada Perusahaan Manufaktur yang terdaftar di Bursa Efek Indonesia. Skripsi. Fakultas Ekonomi Universitas Udayana.

Agus Sartono. 2010. Manajemen Keuangan Teori dan Aplikasi (4th ed.). Yogyakarta: BPFE. 
Anwar, A dan Z. Baridwan. 2006. Effect of Employee Stock Option Plans (ESOPs) to Peformance and Firm Value: Empirical Study at JSX. Simposium Nasional Akuntansi 9. Padang.

Arnita, S. 2015. Pengaruh hibah esop pada kinerja perusahaan dan implikasinya pada return saham perusahaan di bursa efek Indonesia. Tesis. Universitas Udayana.

Bapepam. 2002. Studi tentang Penerapan ESOP Perusahaan Publik di Pasar Modal Indonesia. Departemen Keuangan Republik Indonesia.

Brenner, M., R.K Sundaram. dan D.Yermack. 2000. "Altering the Term of Executive Stock Options.” Journal of Financial Economics.103-128

Chiraz, Djerbi and Jarboui Anis. 2013. Earnings Management and Performance of French IPO Companies. Journal of Accounting and Taxation, 5(1): pp: 114.

Christie, A.A. and Zimmerman J. L. 1994. Efficient and Opportunistic Choices of Accounting Procedures: Corporate Control Contests. The Accounting Review, 69: pp: 1-41.

Christiawan, Y. J. dan J. Tarigan. 2007. Kepemilikan Manajerial: Kebijakan Hutang, Kinerja dan Nilai Perusahaan. Jurnal Akuntansi dan Keuangan. Vol.1. mei 2007. Hal:-8.

Dechow, Patricia M., Richard G. Sloan and Amy P. Sweeney. 1995. Detecting Earnings Management. The Accounting Review, 70(2): pp: 193-225.

Enomoto, Masahiro, Fumihiko Kimura and Tomoyashu Yamaguchi. 2015. Accrual-Based and Real Earnings Management: An International Comparison for Investor Protection. Discussion Paper Series RIEB, pp:141.

Eisenhardt, Kathleen M. 1989. Agency Theory: An Assessment and Review. Academy of Management Review, 14 (1), hal.57-74.

Febrina dan I G N Agung Suaryana. 2011. Faktor-Faktor Yang Mempengaruhi Kebijakan Pengungkapan Tanggungjawab Sosial Dan Lingkungan Pada Perusahaan Manufaktur Di Bursa Efek Indonesia. Simposium Nasional Akuntansi XIV Aceh. 2011.

Ghozali, Imam. 2009. Aplikasi Analisis Multivariate Dengan Program SPSS. Edisi Keempat. Semarang: Badan Penerbit Universitas Diponegoro.

Hartono, Agus. 2014. Pengaruh Employee Stock Option Plan Terhadap Kinerja Perusahaan Publik di Bursa Efek Indonesia. Jurnal Modus. Vol. 26, No.1, Hal:85-91 Universitas Atmajaya Yogyakarta. 
Jensen, M.C., and Meckling, W.H. 1976. Theory of the Firm: Managerial Behavior, Agency Costs, and Ownership Structure. Journal of Financial Economic 3, pp: 305-360.

Maiyusti, Anisa. 2014. Pengaruh Asimetri Informasi, Kepemilikan Manajerial Dan Employee Stock Ownership Program Terhadap Praktik Manajemen Laba (Pada Perusahaan Manufaktur Yang Terdaftar di Bursa Efek Indonesia Tahun 2007-2012). Jurnal Universitas Negeri Padang. Hal: 128

Mulford, Charless W. dan Eugane E. Comiskey. 2002. Deteksi Kecurangan Akuntansi, The Financial Numbers Game. Penerjemah Aurolla S. Harahap dan Yudith D. Anggraeni. Jakarta: PPM.

Nawawi, H. Handari. Manajemen Sumber Daya Manusia untuk Bisnis yang Kompetitif Cetakan kelima. Yogyakarta: Gajah Mada University Press, 2003.

Raharjaputra, Hendra S. 2009. Manajemen Keuangan dan Akuntansi Untuk Eksekutif Perusahaan. PT Raja Grafindo Persada. Jakarta

Riaz, F., F.A Razzaq, and A. Waqar. 2017. Effect of Employee Stock Ownership Plans (ESOPs) on the performance of Small business in Karachi. EJournal Department of Business Administration Iqra University, pp:1-15

Ross, S. A., Westerfield, R . W., \& Jaffe, J (2010). Corporate Finance $9^{\text {th }}$ edition, New York; McGraw- Hill/Irwin.

Sari, Rizkia Anggita. 2012. Pengaruh Karakteristik Perusahaan Terhadap Corporate Social Responsibility Disclosure pada Perusahaan Manufaktur yang Terdaftar di Bursa Efek Indonesia. Jurnal Nominal, 1(1). Universitas Negeri Yogyakarta

Sandyaswari, Ni Putu. 2016. Indikasi Manajemen Laba Pada Perusahaan yang Melakukan Right issue dan Pengaruhnya Terhadap Kinerja Perusahaan. Skripsi. Program Ekstensi Fakultas Ekonomi dan Bisnis Universitas Udayana, Denpasar.

Schipper, K. 1989. Earnings Management. Accounting Horizons, 3: h: 91-106

Singapurwoko, Arif dan Muhhamad Shalahuddin Mustofa El-Wahid. 2011. The Impact of Financial Leverage to Profitability Study of Non-Financial Companies Listed in Indonesia Stock Exchange. Eorupean Journal of Economics, Finance and Administrative Science, pp: 137-148: Issue 32: ISSN 1450-227. 
I G.N Bayu Kuta Waringin dan Luh Gede Krisna Dewi. Pengaruh...

Solimun. 2010. Analisis Multivariat Pemodelan Struktural Metode Partial LeastSquare- PLS. Penerbit CV. Citra: Malang

Thi, Lua Luong. 2015. Earnings Management Through Accrual-Based Analysis. Tesis. Degree Programme International Business Arcada, Helsinki. 